\title{
Fraternal twins: Swiprosin-1/EFhd2 and Swiprosin-2/EFhd1, two homologous EF-hand containing calcium binding adaptor proteins with distinct functions
}

\author{
Sebastian Dütting, Sebastian Brachs, Dirk Mielenz
}

\begin{abstract}
Changes in the intracellular calcium concentration govern cytoskeletal rearrangement, mitosis, apoptosis, transcriptional regulation or synaptic transmission, thereby, regulating cellular effector and organ functions. Calcium binding proteins respond to changes in the intracellular calcium concentration with structural changes, triggering enzymatic activation and association with downstream proteins. One type of calcium binding proteins are EF-hand super family proteins. Here, we describe two recently discovered homologous EF-hand containing adaptor proteins, Swiprosin-1/EF-hand domain containing 2 (EFhd2) and Swiprosin-2/EF-hand domain containing 1 (EFhd1), which are related to allograft inflammatory factor-1 (AIF-1). For reasons of simplicity and concision we propose to name Swiprosin-1/EFhd2 and Swiprosin-2/EFhd1 from now on EFhd2 and EFhd1, according to their respective gene symbols. AlF-1 and Swiprosin-1/EFhd2 are already present in Bilateria, for instance in Drosophila melanogaster and Caenhorhabditis elegans. Swiprosin-2/EFhd1 arose later from gene duplication in the tetrapodal lineage. Secondary structure prediction of AIF-1 reveals disordered regions and one functional EF-hand. Swiprosin-1/EFhd2 and Swiprosin-2/EFhd1 exhibit a disordered region at the N-terminus, followed by two EF-hands and a coiled-coil domain. Whereas both proteins are similar in their predicted overall structure they differ in a non-homologous stretch of 60 amino acids just in front of the EF-hands. AIF-1 controls calcium-dependent cytoskeletal rearrangement in innate immune cells by means of its functional EF-hand. We propose that Swiprosin-1/EFhd2 as well is a cytoskeleton associated adaptor protein involved in immune and brain cell function. Pro-inflammatory conditions are likely to modulate expression and function of Swiprosin-1/EFhd2. Swiprosin-2/EFhd1, on the other hand, modulates apoptosis and differentiation of neuronal and muscle precursor cells, probably through an association with mitochondria. We suggest furthermore that Swiprosin-2/EFhd1 is part of a cellular response to oxidative stress, which could explain its pro-survival activity in neuronal, muscle and perhaps some malignant tissues.
\end{abstract}

\section{Introduction}

Calcium ions $\left(\mathrm{Ca}^{2+}\right)$ regulate enzyme activities, cytoskeletal and transcriptional regulation, mitosis or apoptosis, gene expression, synaptic communication and homeostasis of reactive oxygen species (ROS) [1]. Changes in the intracellular $\mathrm{Ca}^{2+}$ concentration therefore control cellular effector as well as organ functions, such as immune cell activation or brain function, to name only

\footnotetext{
* Correspondence: dmielenz@molmed.uni-erlangen.de

Division of Molecular Immunology, Department of Medicine III, Nikolaus Fiebiger Center, University of Erlangen-Nürnberg, 91054 Erlangen, Germany
}

a few. $\mathrm{Ca}^{2+}$ signaling is a consequence of temporary and/or local increases in the intracellular $\mathrm{Ca}^{2+}$ concentration, through the opening of $\mathrm{Ca}^{2+}$ channels in the endoplasmic reticulum (ER) and the plasma membrane. $\mathrm{Ca}^{2+}$ acts as a ubiquitous, diffusible second messenger that is stored in the ER and mitochondria. It diffuses from the ER into the cytoplasm due to opening of $\mathrm{Ca}^{2+}$ channels in the ER membrane in response to increases in inositol-1,4,5-trisphosphate $\left(\mathrm{IP}_{3}\right)$, a metabolite of the cleavage of phosphatidylinositol-4,5-bisphosphate $\left(\mathrm{PIP}_{2}\right)$ by members of the PI-phospholipase C family of 
enzymes. A wide variety of cell surface receptors including growth factor receptors, cytokine receptors, Gprotein coupled receptors (GPCR), integrins, the high affinity receptor for immunoglobulin E (IgE) - FceR1 on mast cells as well as $\mathrm{B}$ and $\mathrm{T}$ cell receptors (BCR and TCR) can activate phospholipase $\mathrm{C}$ enzymes directly and indirectly through different mechanisms [2]. The depletion of intracellular $\mathrm{Ca}^{2+}$ stores and the concomitant rise in the cytosolic $\mathrm{Ca}^{2+}$ concentration induces influx of extracellular $\mathrm{Ca}^{2+}$ across the plasma membrane through store operated calcium entry (SOCE) and calcium release activated calcium (CRAC) channels. Key players in this process are stromal interaction molecules 1 and 2 (STIM1 and 2), which sense the depletion of ER $\mathrm{Ca}^{2+}$ stores, and ORAI1, which represents a pore subunit of the CRAC channel (for review see references $[3,4])$.

$\mathrm{Ca}^{2+}$-binding proteins of the EF-hand super family [5-7] are involved in all of the above-mentioned cellular processes. EF-hand bearing proteins are heterogeneous in their structures and calcium binding properties. R. $\mathrm{H}$. Kretsinger, who discovered a $\mathrm{Ca}^{2+}$-binding helix-loophelix motif in the structure of Parvalbumin [8], named this motif "EF-hand". The corresponding linear sequence motif (Pfam PF00036; http://pfam.sanger.ac.uk/) has thereafter been discovered in the amino acid sequences of many other calcium-binding proteins [9-13]. Here, we provide information about the recently described EF-hand proteins Swiprosin-1/EFhd2 and Swiprosin2/EFhd1, which are related to another EF-hand protein, allograft inflammatory factor-1 (AIF-1; also: Iba1, ionized calcium binding adapter molecule 1). Although our own work focuses on B cell development and signaling we provide information for a broader readership here. There are many synonyms for Swiprosin/EFhd genes, transcripts and proteins (Additional file 1, Table S1). Whereas the nomenclature of the genes is unambiguous, alternative names complicate work with the proteins (Additional file 1, Table S1). For simplicity and concision, we propose to name the proteins from now on EFhd1 and EFhd2, according to their respective gene symbols. Hence, we will refer in this review and future publications to Swiprosin-1/EFhd2 as EFhd2 and to Swiprosin-2/EFhd1 as EFhd1.

EFhd2 and EFhd1 exhibit similar predicted secondary structures (http://elm.eu.org) (Figure 1a), with disordered regions at the $\mathrm{N}$-terminus, predicted and functional SH3-domain binding sites [14], followed by two EF-hands and a coiled-coil domain at the C-terminus. Both proteins bind indeed $\mathrm{Ca}^{2+}[15,16]$ and exhibit a high degree of sequence identity at the protein level $(64.58 \%)$ (Figure 1b). The only significantly different region are amino acids (aa) 20-80 (referring to the numbering of EFhd2). A part of this region (aa 70-78) has been shown by us to be important for targeting EFhd2 to detergent resistant membranes (DRM) in the murine B cell line WEHI231 [14]. Both EFhd2 [14] and EFhd1 (Additional file 2, Figure S1) are conserved amongst species, with an orthologue of EFhd2 in Drosophila melanogaster (CG10641). Interestingly, regarding EFhd2 and EFhd1 from the same species (Figure 1a), or either EFhd2 [14] and EFhd1 (Additional file 2, Figure S1) from different species, aa 20-80 differ the most. Since EFhd2 and EFhd1 are so similar in their other domains, this part of the proteins is likely to specify distinct functions of EFhd2 and EFhd1. One would therefore assume that EFhd2 and EFhd1 bind proteins redundantly as well as uniquely. When expressed in the same cellular context, EFhd2 and EFhd1 might transmit $\mathrm{Ca}^{2+}$ signals into a different signaling outcome, especially because there is so far no evidence for an interaction of EFhd2 with EFhd1 (D.M. et al., unpublished data).

\section{Evolution of the genes encoding AIF-1 (aif1), EFhd2 (efhd2) and EFhd1 (efhd1)}

The first efhd/aif1 precursor gene is present in an ancestral species of the animal taxon Bilateria (Figure 2; http://www.treefam.org/cgi-bin). This ancient gene underwent duplication in an unknown species, giving rise to two branches. One branch represents efhd and aif1, both of which gene products exhibit EF-hand domains (one in AIF-1 and two in EFhd). The other branch represents a gene encoding a unique protein in C. elegans (WP:CE38519) (Figure 2, bottom) that consists only of a coiled-coil domain at the C-terminus (not shown). The efhd gene products contain a disordered region, two central EF-hands and a C-terminal coiled-coil domain whereas AIF-1 contains only a disordered region and two EF-hands, the second of which is degenerate. Accordingly, the homology between aif1 and efhd genes is restricted to the region encoding the EF-hand domains (representative result for murine EFhd2 is shown in Additional file 3, Figure S2). This suggests that calcium binding is the most prominent feature of this protein family. The aif1/efhd precursor underwent a second duplication, resulting in aif1 genes and the efhd 2 precursor. The efhd 2 gene is already present in insects where it represents the only efhd gene (Figure 2). In one species of the taxon Euteleostomi, after the onset of Chordata development, the ancient efhd 2 gene was duplicated once more, now representing two genes, efhd 2 and efhd1, encoding for the proteins EFhd2 and EFhd1. These are - amongst other species - present in man, mouse, rat, chicken, zebrafish and frog. In the tetrapodal lineage, putatively during or before development of Xenopus spec., there was yet another duplication of the efhd 2 gene. Thus, Xenopus tropicalis contains three efhd genes, efhd1, 

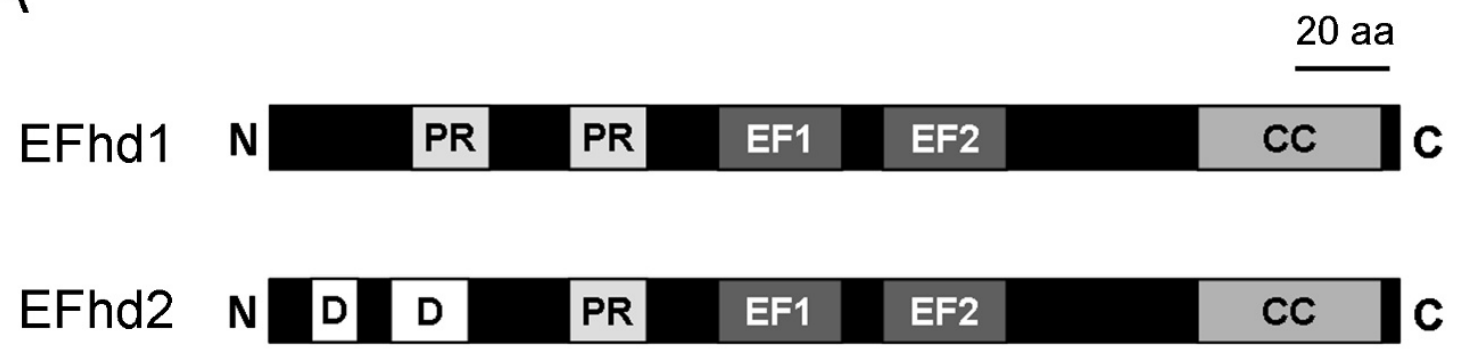

B

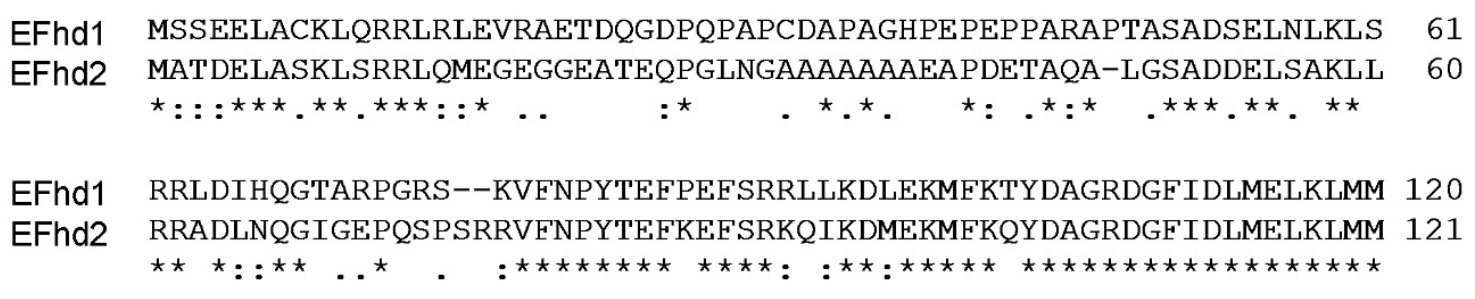

EFhd1 EKLGAPQTHLGLKSMIKEVDEDFDGKLSFREFLLIFHKAAAGELQEDSGLLALAKFSEIDV 181

EFhd2 EKLGAPQTHLGLKSMIQEVDEDFDSKLSFREFLLIFRKAAAGELQEDSGLHVLARLSEIDV 182

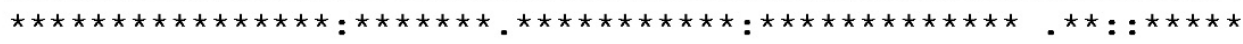

EFhd1 ALEGVRGAKNFFEAKAQALSCSSKFEAELKAEQEERKREEEARRLRQAAFRELKAAFSA

EFhd2 STEGVKGAKNFFEAKVQAINVSSRFEEEIKAEQEERKKQAEEVKQRKAAFKELQSTFK-

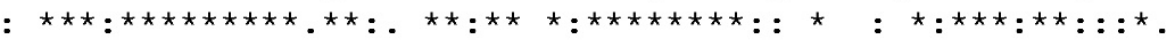

Figure 1 Predicted secondary structures and sequence comparisons of EFhd2 and EFhd1. a) Predicted secondary structures of murine EFhd1 and EFhd2 (240 aa) (http://elm.eu.org). PR: proline-rich elements (potential SH3 domain-binding sites), EF: EF-hands, CC: coiled-coil domain, D: disordered region. b) Aligment of murine EFhd1 (Q9D4J1) and EFhd2 (Q9D8Y0) sequences using ClustalW2 (http://www.ebi. ac.uk/clustalw). Amino acid (aa) positions are marked on the right. "*", identical aa, ":", conserved aa, "." semi conserved aa.

efhd 2 and a third unique gene that is still lacking a proper name (ensxett00000029488_xentr). Interestingly, the gene product of ensxett00000029488_xentr contains no EF-hands, but only disordered regions and a coiled-coil domain. This protein might therefore compete with the EF-hand containing Xenopus EFhd2 and EFhd1 for calcium-independent binding partners. In summary, EFhd2 is the ancestral protein, being present for instance in worms and insects, and EFhd2 and EFhd1 co-exist from the euteleostomic lineage on, for instance in zebrafish, frog and later evolutionary stages. This provokes the question as to whether the gene duplication resulting in the efhd 1 gene provided an evolutionary advantage.

\section{Chromosomal location of the human and murine genes efhd 2 and efhd 1}

The murine efhd 2 gene is located on chromosome 4 (see http://www.ensembl.org for further details). It contains 4 exons with a long intron between exon 1 and $2(15 \mathrm{~kb})$ and a long 3'-UTR in exon 4 (approx. $1.6 \mathrm{~kb}$ ). This structure is conserved in humans where the efhd2 gene is located on chromosome 1 . The murine efh 2 gene is located centrally in a susceptibility locus for SLE (Systemic Lupus Erythematodes) (LMB-1, close to D4Mit33) on chromosome 4 [17]. The human efhd2 gene lies in the PARK7 locus (1p36.33 - 1p36.12) that is associated with autosomal recessive early onset Parkinson's disease [18]. For the human efhd2 gene product, EFhd2, three protein-coding splice variants have been predicted, translating into putative protein products of 177 to 240 aa. The murine efhd 1 gene is localized on chromosome 1 . It is also comprised of 4 exons with an even longer intron between exons 1 and 2 (approx. 25 $\mathrm{kb}$ ), similar to human efhd1 (chromosome 2). For the human efhd1 gene product, EFhd1, five protein-coding splice variants are predicted, resulting in potential protein products of 81 to 239 aa. 


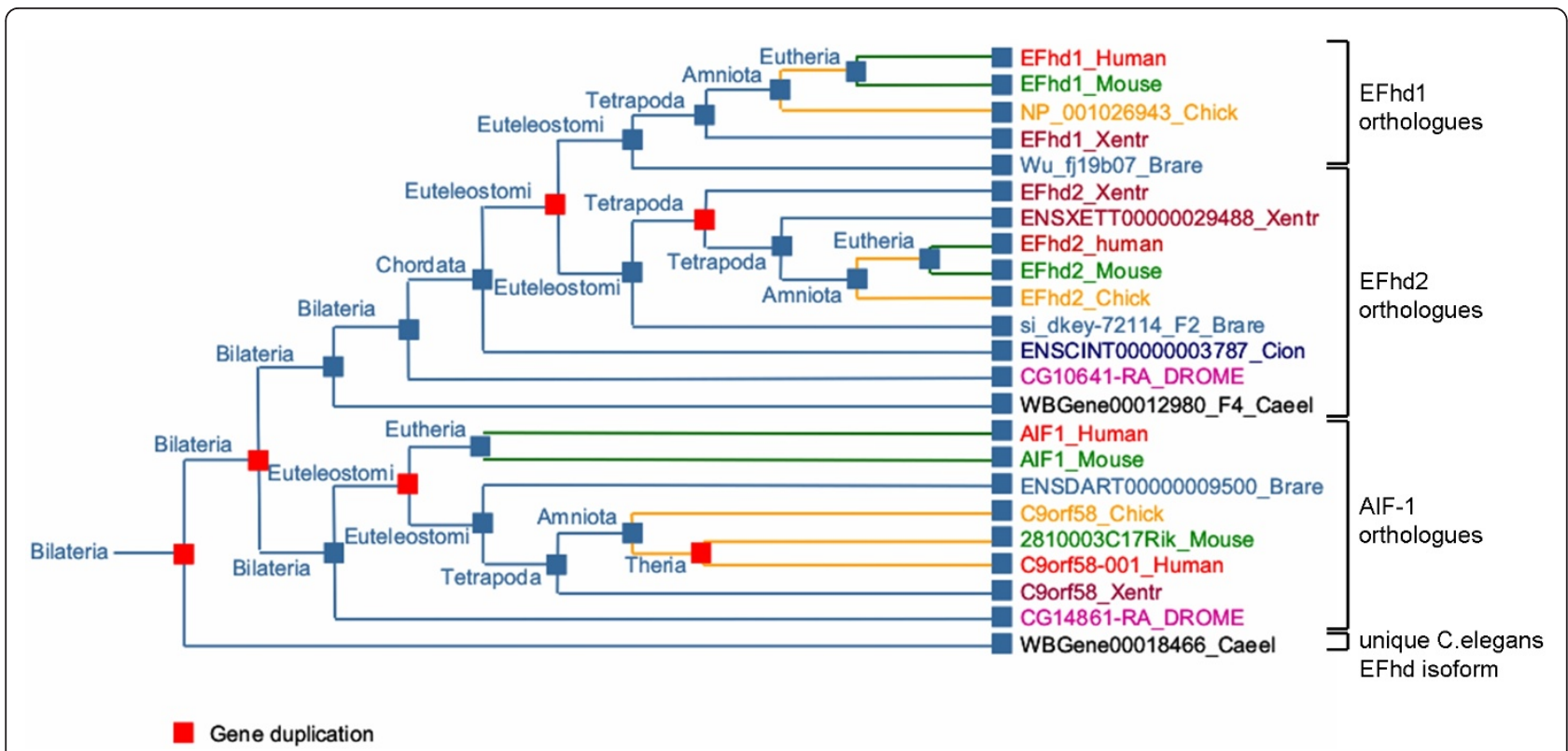

Figure 2 Phylogeny of EFhd genes. A phylogenetic tree with equal distances between different taxons was generated using efhd 1 as search parameter (http://www.treefam.org/cgi-bin). Search parameters were: accession number TF320736 / clean / equal distance / show taxa / none / $\exp /$ selected species. Only representative species are shown for convenience. On the right hand side the employed transcript sequences are shown. Chick, chicken (Gallus gallus), Brare, zebrafish (Danio rerio), Xentr, frog (Xenopus tropicalis), Cioin, Hydra (Ciona intestinalis), Drome, fruitfly (Drosophila melanogaster), Caeel, worm (Caenorhabtidis elegans).

\section{EFhd2}

\section{Expression of EFhd2}

An enhancer trap screen has identified a Drosophila strain with an intriguing expression pattern in muscle cells and somatic muscle precursor cells. The insertion is in the Drosophila efhd homologue, CG10641 [19]. Furlong et al. [20] revealed expression of CG10641 by microarray analyses and in situ hybridization during mesoderm development. Estrada et al. show expression of CG10641 in the visceral and somatic mesoderm, stage 9 ventral head mesoderm, stage 10 head mesoderm and in hemocytes but did not follow up the expression patter of CG10641 during mesoderm differentiation [21]. However, based on these expression data Kiefer et al. [22] propose a function for all Drosophila CG10641-related genes in muscle. Indeed, Renate Renkawitz-Pohl's group (C. Hornbruch and R. Renkawitz-Pohl, personal communication) shows expression of Drosophila EFhd (CG10641 encoded) in hematocytes and during myoblast fusion. The EFhd2 orthologue in C. elegans is expressed in pharynx, body wall muscle, the nervous system and the ventral nerve cord. In zebrafish the associated ESTs are expressed in brain, eye, genitourinary tissue, gills, muscle, and olfactory rosettes. In C. elegans, zebrafish and mouse the respective orthologues may have additional functions, including a role in the nervous system [22]. The latter appears to be true in human and mouse, at least under pathological conditions such as neurodegeneration, schizophrenia and alcohol addiction [15,23-25].

Muscle is derived from mesoderm but the mesoderm gives also rise for instance to bone (osteoblasts and osteoclasts), connective tissue and hematopoietic cells. In humans, EFhd2 becomes transiently up-regulated during osteoblast differentiation from human mesenchymal stem cells [26]. EFhd2 is also up-regulated during differentiation of the murine RAW264 macrophage cell line into osteoclasts after treatment with RANK-L (receptor activator of NF- $\kappa \mathrm{B}$ ligand) [27]. Other cell types of mesodermal origin expressing EFhd2 are particularly immune cells: EFhd2 is expressed in human and primary murine mast cells [[28,29]; our unpublished data], human and murine $\mathrm{B}$ cells [30-32], in $\mathrm{CD} 4^{+}$and $\mathrm{CD} 8^{+} \mathrm{T}$ cells [32-34], natural killer cells (NK cells) [35] and human peripheral blood mononuclear cells (PBMC) [36,37]. PBMC are a heterogeneous cell population of lymphocytes $(\sim 75 \%$ $\mathrm{CD} 4^{+}$and $\mathrm{CD}^{+} \mathrm{T}$ cells and $\sim 25 \% \mathrm{NK}$ and B cells), monocytes and macrophages. In accordance, murine efhd 2 mRNA is present at relatively high abundance in total spleen by Northern Blot, at similar levels in liver and lung, and at relatively low amounts in kidney [31]. The highest expression of efhd 2 has, however, been detected in ectodermal tissue, namely brain [31]. Likewise, the murine EFhd2 protein was identified in mouse brain [38], specifically in brain stem, cerebellum, 
amygdala, striatum, cortex and frontal lobe [15] as well as in the hippocampus $[15,23]$. With the exception of microglia cells [39] it remains to be established which cell type(s) in the brain express EFhd2. Other cells of ectodermal origin expressing EFhd2 are primary immortalized human keratinocytes [40]. Finally, during mouse development EFhd2 is detected strongly in ectodermal tissue such as the most rostral foregut and the caudal hindgut at E8.5 [41]. In addition, EFhd2 is also downregulated in embryos deficient for the transcription factor Foxa2 and is a marker of definitive endoderm [41]. Interestingly, EFhd2 is already present in murine embryonic stem cells (our unpublished data). Cell lines expressing EFhd2 are all murine B cell lines we analyzed (our unpublished data), HeLa cells [42] and NIH3T3 cells (our unpublished data). In summary, in worm, zebrafish and higher vertebrates EFhd2 is not only expressed during mesoderm development but also in endodermal and ectodermal tissues. Whether this is also the case in D. melanogaster remains to be determined.

\section{Involvement of EFhd2 in immune cell activation}

Innate immune cells respond to pathogen associated molecular patterns (PAMP) and to danger signals released by necrotic cells. Many signaling elements that are important in adaptive immunity have recently also been shown to control innate immunity [43]. Interestingly, signaling molecules of innate immune cells in higher organisms are shared even in Drosophila where they control for instance removal of necrotic tissue [43]. Although insects do not possess an adaptive immune system and rely solely on their innate immune system, they utilize ITAMs (immunoreceptor tyrosine based activation motifs). The ITAM is a tyrosine phosphorylation consensus motif $\left(\operatorname{YxxLx}_{(7-12)} \mathrm{YxxL}\right)$ [44] found in many receptors and co-receptors of the adaptive and innate immune system as well as in ERM (ezrin, radixin, moesin) proteins [43]. When phosphorylated on their tyrosine residues by Src kinases or Syk (splenic tyrosine kinase) [45], ITAMs bind the SH2 domains of Syk, relieving Syk from autoinhibition and eventually activating it, resulting in a positive feedback loop [45]. Syk is key to signaling from adaptive as well as many innate immune receptors $[43,46]$. We have recently shown that murine EFhd2 is a positive regulator of Syk activity in response to $B C R$ stimulation in the murine $B$ cell line WEHI231 [14].

Hemocytes of insects are crucial players of immune surveillance by migrating through the body, phagocyting invading pathogens and secreting antimicrobial peptides [47]. One type of hemocytes are the plasmatocytes which resemble mammalian monocytic and macrophage cells [47]. Differentiated macrophage-like hemocytes of Drosophila express the Drosophila EFhd protein
(C. Hornbruch and R. Renkawitz-Pohl, personal communication). This fits to other reports revealing Drosophila EFhd expression in hemocytes [48] and in the Drosophila S2 cell line which exhibits phagocytotic activity [47]. Many of the hematopoietic factors have been conserved across taxonomic groups [43]. Likewise, EFhd2 is expressed in the murine monocyte cell line RAW264 [27], in human PBMC [36], in microglia cells [39] and in NK-like cells [35]. EFhd2 becomes upregulated - together with actin - in response to stimulation of the human monocyte cell line THP-1 with a recombinant Mycobacterium bovis strain [49]. This stimulation improved the antigen-presenting capacity of THP- 1 cells, the CD ${ }^{+}$immune response and TNF- $\alpha$ production [49]. To sum up, EFhd2 is expressed across species in many cell types of the innate and adaptive immune system. It is tempting to speculate that EFhd2 is involved in Syk activation downstream of other immune receptors than the BCR and plays a role in antigen presentation.

\section{Connection of EFhd2 to the cytoskeleton}

Migration and phagocytotic activity of macrophages require a dynamic cytoskeleton. For instance, the small GTPase Cdc42 is required for cellular polarity, formation of filopodia and Fc $\gamma$-receptor mediated phagocytosis $[50,51]$. Rac is required for cell migration and Fc $\gamma$ receptor mediated phagocytosis $[50,52,53]$ and Rho is required to retract the trailing edge of migrating cells and for uptake of apoptotic cell fragments $[50,54]$. EFhd2 is associated with the cytoskeleton in the human mast cell line HMC-1 and in NK-like cells [29,35]. More specifically, EFhd2 is associated in a caspase-9-containing complex with the cytoskeletal protein ezrin [55]. In the brain of a mouse model (JNPL3 mouse) [56] for neurodegeneration (frontotemporal dementia and parkinsonism linked to chromosome 17; FTDP-17), where neurodegeneration and neuroinflammation are induced through transgenic expression of a mutated human tau gene (htau P301L), EFhd2 was identified in a complex with the transgenic human tau protein [15]. In addition, endogenous EFhd2 and tau associate in brain lysates of humans with Alzheimer's disease and FTDP-17 [15]. Finally, EFhd2 becomes dephosphorylated after epidermal growth factor (EGF) stimulation of HeLa cells with the same kinetics as the actin binding protein gelsolin [42]. Taken together, these data demonstrate that EFhd2 is associated with the cytoskeleton but the exact connection is unknown at present. However, the related AIF-1 is associated with the cytoskeleton as well and involved in macrophage survival, migration and activation [57]. Specifically, it augments macrophage phagocytotic activity [58]. Calcium binding to AIF-1 by means of its functional EF-hand is required for its ability to activate Rac 
or G-CSF expression in vascular smooth muscle cells [59]. Similarly, EFhd2 also binds calcium directly [15] which may lead to interactions with cytoskeletal regulators to modulate functions of innate immune cells, such as cell migration, phagocytosis and antigen presentation. In fact, in the human mast cell line HMC-1 EFhd2 co-localizes with, and modulates F-actin [29].

\section{Involvement of EFhd2 in NF- $\kappa$ B regulation}

In the human mast cell line HMC-1 (which lacks the Fce receptor) EFhd2 augments expression of proinflammatory cytokines after phorbol myristyl acetate (PMA)/ionomycin stimulation. Similarly, AIF-1 augments expression of IL-6, IL-12 but also IL-10 after lipopolysaccharide (LPS) stimulation of macrophages [60]. Therefore, in macrophages and a mast cell line, perhaps also in primary mast cells (where EFhd2 is expressed; our unpublished data), EFhd2 appears to reveal proinflammatory activities, perhaps through positive regulation of the protein kinase $\mathrm{C} \beta$ /nuclear factor $\kappa \mathrm{B}(\mathrm{PKC} \beta$ / $\mathrm{NF}-\kappa \mathrm{B})$ signaling pathway [29]. The PKC $\beta$ pathway is also activated by the BCR downstream of PLC $\gamma 2 / \mathrm{Ca}^{2+}$ signaling and induces eventually $\mathrm{NF}-\kappa \mathrm{B}$ activation through the Carma1/Bcl10/MALT1 complex [61]. A positive regulation of $\mathrm{PKC} \beta / \mathrm{NF}-\kappa \mathrm{B}$ through EFhd2 would therefore be expected as we showed recently that EFhd2 augments BCR-induced Syk/PLC $\gamma 2 / \mathrm{Ca}^{2+}$ signaling in the murine B cell line WEHI231 [14]. Unexpectedly, however, we showed already that EFhd2 rather blocks expression of the anti-apoptotic NF- $\kappa \mathrm{B}$ target gene $b c l x L$ [31]. An explanation could be that EFhd2 binds calcium directly [15] and is therefore part of a negative feedback loop preventing NF- $\kappa \mathrm{B}$ activation after BCR stimulation (Figure 3). Apoptosis in lymphocytes is effectively controlled by the transcription factor $\mathrm{NF}-\kappa \mathrm{B}$ [62]. In the murine B cell line WEHI231 that is susceptible to BCR-induced apoptosis, EFhd2 positively regulates spontaneous and BCR-induced apoptosis [31]. Silencing of EFhd2 by shRNA augments survival of WEHI231 cells spontaneously and in response to BCR stimulation. In contrast, G1 cell cycle arrest and p27Kip up-regulation are still induced by BCR ligation in the absence of EFhd2 [31]. To conclude, EFhd2 regulates specifically apoptosis, but not cell cycle arrest in WEHI231 cells. We propose that this is due to suppression of the NF- $\kappa \mathrm{B}$ pathway in this cell line. The proapoptotic activity of EFhd2 was suppressed by three stimuli that activate NF- $\kappa \mathrm{B}$ (CD40 ligation, LPS, and B cell activating factor of the TNF family [BAFF]) [31]. These data seem to oppose data from the mast cell line HMC-1 where EFhd2 augmented up-regulation of NF$\mathrm{kB}$ target genes after PMA/ionomycin stimulation [29], many of which are anti-apoptotic. However, PMA/ionomycin stimulation as used in HMC1 cells [29] and BCR ligation in WEHI231 cells are different stimuli. EFhd2 may enhance BCR-mediated cell death in WEHI231 cells through inhibition of the NF- $\kappa$ B pathway but, through an unknown molecular switch, enhance likewise the NF- $\kappa \mathrm{B}$ activating and anti-apoptotic activities of CD40, LPS, and BAFF in combination with BCR stimulation.

\section{Engagement of EFhd2 in autoimmune disorders}

Regulation of the NF- $\kappa \mathrm{B}$ pathway by EFhd2, be it positive or negative, together with its expression in innate and adaptive immune cells and its effects on cytokine production [29] argue for involvement of EFhd2 in normal and pathological immune activation. In fact, PBMC of rheumatoid arthritis (RA) patients express less EFhd2 protein than PBMC of healthy patients [36]. Moreover, there is a protease-mediated cleavage of EFhd2 in RA patients [37]. Expression of pro-apoptotic factors in both $\mathrm{B}$ and $\mathrm{T}$ cells is important to establish tolerance of the adaptive immune system [63]. If EFhd2 was downregulated in B cells their survival might be prolonged. This might contribute to the persistence of autoimmune diseases such as RA and SLE [64]. Interestingly, the EFhd2-related AIF-1 is involved in RA as well [57]. Moreover, the murine efhd 2 gene is Iocated rather centrally in an SLE susceptibility region (LMB-1, close to D4Mit33) on chromosome 4 [17], thereby, representing a putative genetic determinant of SLE. Memory B cells become persistently re-activated in RA and SLE [65]. In memory B cells as well as in $\mathrm{CD}^{+}$and $\mathrm{CD}^{+}$memory $\mathrm{T}$ cells, efhd2 expression is part of an evolutionary conserved transcriptional signature [32]. Whether efhd2 expression in immune memory cells is important for their activation, to keep them silent, or to help them patrolling through secondary lymphatic organs is unknown at present but certainly deserves further investigation with respect to autoimmune diseases.

\section{EFhd2 and neuropathological disorders}

Neurodegenerative disorders associated with tau, so-called tauopathies, are characterized by successive deposition of protein aggregates consisting of hyperphosphorylated tau [66,67]. In Parkinson's patients, tau and nitrated $\alpha$-synuclein induce formation of so-called Lewy bodies that are characteristic for Parkinson's disease [68]. Tau aggregates and Lewy bodies cause synapse loss and neuronal cell death. In addition, neurodegenerative diseases reveal an inflammatory component represented mainly by microglial activation [69]. There are several lines of evidence that EFhd2 is involved in normal and pathological brain function: First, in microglia cells, EFhd2 becomes up-regulated and secreted in response to stimulation with nitrated $\alpha$-synuclein [39]. Very interestingly, the related AIF-1 (Iba1) is a microglial 


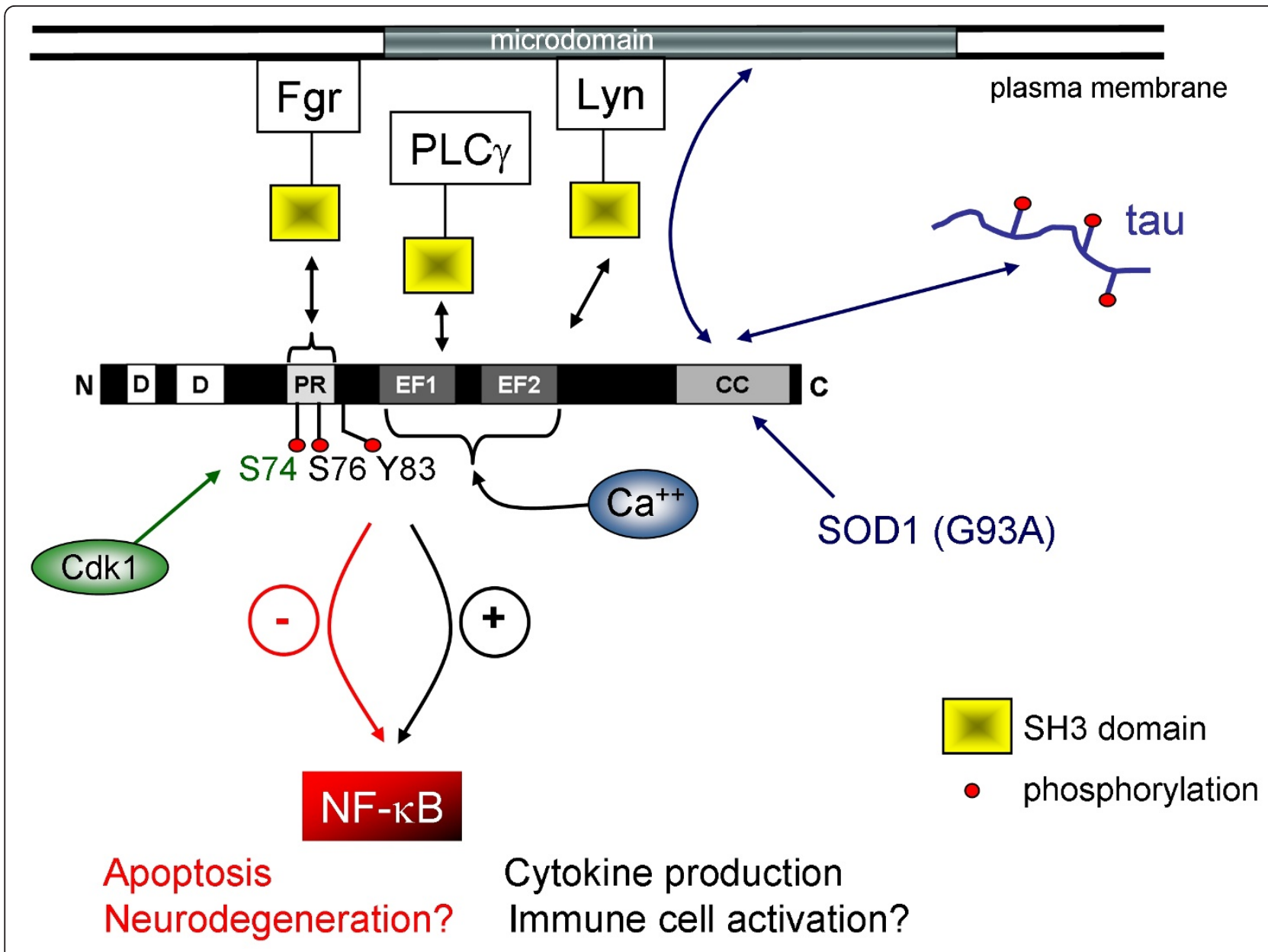

Figure 3 Involvement of EFhd2 in membrane and cytoskeleton associated pathways. EFhd2 can associate with detergent resistant membranes (DRM) thought to represent membrane rafts in some B cell lines. Membrane raft association of EFhd2 was also detected in nervous tissue of mice that express a gain of function mutant (G93A) of SOD1. EFhd2 has been shown to exhibit NF- $\kappa$ B-activating as well as NF- $\kappa$ Binactivating functions in different cell types. Through regulation of NF- $\kappa \mathrm{B}$, EFhd2 may regulate survival or apoptosis of diverse cell types. The interactions of EFhd2 with the SH3 domains of Lyn, PLC $\gamma$ and Fgr are based on GST-Pull down experiments using recombinant SH3 domains (see Ref. 14). The interactions of Fgr and Lyn SH3 domains with EFhd2 depend on phosphorylation and the SH3 domain of Fgr binds to the predicted proline-rich (PR) SH3 domain binding region of EFhd2. Three phosphorylation sites of EFhd2 are known: S74, S76 and Y83. S74 is a cyclin dependent kinase 1 ( $\mathrm{Cdk} 1)$ site. The ability of EFhd2 to bind calcium may regulate its function and its association with the cytoskeleton. EFhd2 also interacts with hyperphosphorylated Tau in a FTDP17 mouse model as well as in FTDP17 and Alzheimer's patients.

activation marker [70]. Second, the brain of a FTDP-17 mouse model (JNPL3 mouse) [56] where neurodegeneration and neuroinflammation are induced through transgenic expression of a mutated human tau (htau P301L) contains complexes of the transgenic human tau protein and endogenous EFhd2 [15] (Figure 3). In addition, endogenous EFhd2 and tau associate in brain lysates of humans with Alzheimer's disease and FTDP17 [15]. Third, EFhd2 is present in membrane rafts of mouse spinal cord, but only when mice over-express a mutant, toxic gain of function form of superoxide dismutase 1 (SOD1), namely the G93A mutant [71] (Figure 3). This mutant is responsible for familial amyotrophic lateral sclerosis, a chronic, progressive neuromuscular disorder [72]. Fourth, EFhd2 is downregulated in Nogo-A knockout mice that reveal increased neurite growth and an increased regeneration potential when compared to wildtype control mice [73]. Fifth, in the frontal cortex of schizophrenic patients EFhd2 becomes up-regulated together with microtubule associated proteins [24]. Whether all these data represent a causative connection of EFhd2 with neurodegenerative diseases on the one hand, with neuronal regeneration on the other hand or are merely secondary effects is not known at present. Given the increasing incidence of neurodegenerative diseases, it would potentially be important to examine EFhd2 expression and function in human inflammatory 
diseases, including neuroinflammatory processes, and in murine mouse models for these diseases.

\section{Involvement of EFhd2 in membrane associated pathways} The plasma membrane contains cholesterol and sphingolipid-enriched microdomains (detergent resistant membranes, DRM) that are thought to function in many membrane-associated processes, such as immune receptor signaling [74]. In addition, microdomains control vesicular trafficking, signaling of various receptors other than immune receptors, and cytoskeletal rearrangement [75]. Microdomains and their associated scaffold proteins have also been implicated in the pathogenesis of several neurological diseases, such as Parkinson's and Alzheimer's disease [76] (see paragraph above). EFhd2 was discovered by us through a proteomic analysis of DRM of B cell lines that differ in their apoptotic response to BCR stimulation [30]. We found that EFhd2 associates with DRM in cell lines which undergo apoptosis after BCR stimulation [30] and indeed, as mentioned above, EFhd2 augments BCR signaling and BCR-induced apoptosis in one of these cell lines examined $[14,31]$. It was tempting to speculate that the DRM association of EFhd2 controls these effects. More recently we could actually show that the BCR-induced increase in intracellular calcium concentration is dependent on the DRM association of EFhd2 in WEHI231 cells [14]. However, EFhd2 was not associated with DRM in the murine B cell line CH27 [30]. We conclude that membrane raft association of EFhd2 is not constitutive but regulated, presumably in a cell type-specific manner. Hence, DRM association of EFhd2, and thereby its function, may be regulated by a specific pathway active in some cell types. There exist two lines of evidence for this hypothesis:

First, the predicted SH3-binding region (aa 70-78) of EFhd2, targeting EFhd2 to DRM, binds specifically to the SH3 domain of the tyrosine kinase Fgr [14] (Figure 3). In B cells, Fgr is only expressed late in B cell development [77] and there is only one study to our knowledge that examined DRM association of Fgr [78]. This study revealed that, in contrast to other Src family kinases, Fgr is not associated with DRM, at least in RAW264.7 cells [78]. Hence, once Fgr is expressed, it could keep EFhd2 out of DRM. The SH3 domain of Lyn that also binds to EFhd2 [14] could conversely maintain DRM association of EFhd2 (Figure 3). While Lyn is expressed throughout B cell development, Fgr is expressed in mature primary B cells, mantle zone B cells and during myelomonocytic differentiation, but not in immature primary B cells $[77,79]$, which might regulate the subcellular localisation and the function of EFhd2 in mature B cells. Interestingly, we observed a phosphorylation-dependent interaction of EFhd2 with Lyn and Fgr
[14]. Phosphorylation of murine and human EFhd2 at serine residues 74 and 76 [80-83] and, in brain lysates, of tyrosine 83 [38], have been described. Lipopolysaccharide stimulation of macrophages does not alter the phosphorylation of EFhd2 significantly [83]. In our hands, EFhd2 was not phosphorylated on tyrosine before or after BCR engagement as judged by western blotting with the anti-pY mAb PY99 (D.M. et al., unpublished data). In conclusion, phosphorylation of either serine 74 or 76 , or both, or other sites would appear to mediate binding of EFhd2 to the SH3 domains of Fgr and Lyn. Interestingly, S74 and S76 of EFhd2 are Cdk1 (cyclin dependent kinase 1) phosphorylation sites [80]. Cdk1 is expressed and active during the G2/S phase of the cell cycle [84], that is, in activated B cells, which are present for instance in germinal centers [85]. Hence, EFhd2 could be modified by phosphorylation to modulate BCR signals in cycling B cells where the BCR induces G1 arrest and apoptosis [86], both of which are enhanced by EFhd2 [31].

Second, EFhd2 is present in DRM of mouse spinal cord, but only when mice over-express a mutant, toxic gain of function form of superoxide dismutase 1 (SOD1), namely the G93A mutant [71]. This mutant is responsible for familial amyotrophic lateral sclerosis, a chronic, progressive neuromuscular disorder [72]. Interactions of DRM with the cytoskeleton have been well documented [75]. Interestingly, the G93A mutant of SOD1 also induces DRM association of cytoskeletal proteins, such as ezrin, clathrin, actin depolymerising factor and Arp2/3 [71] (Figure 3). In accordance, EFhd2 has been identified in a complex with ezrin [55]. Under certain yet to be defined circumstances, EFhd2 may target ezrin, clathrin and others to DRM or become targeted to DRM by cytoskeletal proteins. De-phosphorylation of ezrin after BCR-triggering is important to induce DRM association of the BCR at late time points (more than 15 min) [87]. We have also shown that, at least in the murine B cell line WEHI231, EFhd2 induces constitutive association of the BCR, PLC 2 and Syk with DRMs [14]. Taken together, EFhd2 may function as a DRM - cytoskeleton integrator through as yet not well characterized protein-protein or protein-lipid interactions.

\section{Proposed function(s) of EFhd2}

As detailed above, EFhd2 is a cytoskeleton associated adaptor protein involved in immune and normal as well as pathological neuronal functions, and perhaps in calcium homeostasis. This may be important for immune cell signaling and signaling pathways within or arising from neurological synapses. In accordance, EFhd2 is regulated under inflammatory conditions in immune and brain cells. Hence, we propose that EFhd2 is a modulator of immune and brain cell function under both basal and inflammatory conditions. 


\section{EFhd1}

\section{Expression of EFhd1}

EFhd1 was first described as mitocalcin. It was identified in an attempt to isolate genes involved in neuronal differentiation in $2 \mathrm{Y}-3 \mathrm{t}$ cells, a neuronal progenitor cell line established from an adult p53-deficient mouse cerebellum [88]. In 2Y-3t cells EFhd1 is up-regulated during differentiation. In vivo, EFhd1 is expressed both in cerebellum and cerebrum $[16,88]$. Its expression increases postnatally. In adult mice, neurons of cerebellum, cerebrum and hippocampus (cornu ammonis and dentate gyrus) reveal efhd1 mRNA, but only low amounts are present in the white matter of cerebellum and cerebrum [88]. The Purkinje-layer, the internal granule cell layer and the molecular layer, however, do express EFhd1. In addition, spermatocytes, interstitial cells of adult testis and granulosa cells of the cumulus oophorus (cumulus cells) as well as mural granulosa cells in adult ovary exhibit EFhd1 expression [16,88]. EFhd1 is also expressed in IGF-II-deficient murine C2 myoblasts [89]. There, efhd 1 mRNA ceases in the absence of the transcriptional co-activator p300 [89]. Healthy human renal tissue expresses efhd1 mRNA [90] and in murine kidney the collecting ducts, but not the glomeruli, reveal EFhd1 $[16,88]$. Interestingly, EFhd1 expression is repressed in renal cell carcinoma (RCC) [90]. In contrast, EFhd1 is present in tumour tissues from patients with stage III and IV melanoma and increased expression of EFhd1 is significantly associated with shorter patient survival times [91]. Whereas EFhd1 has been proposed to exhibit tumour suppressing functions in RCC [90], growth promoting functions may be associated with other tumours. Concomitantly, uterine fibroids reveal less efhd1 mRNA than normal myometrium [92]. Under more physiological conditions EFhd1 becomes up-regulated at term when compared with midgestation [93]. In contrast, human endometrial cells down-regulate EFhd1 after trophoblast co-culture [94].

\section{Function of EFhd1 in normal and malignant tissue}

Using an SDS-gel shift assay EFhd1 has been shown to bind calcium [88]. It associates with the mitochondrial inner membrane [16] and over-expression results in neurite extension of 2Y-3t cells. Conversely, down-regulation of EFhd1 through siRNA suppresses neurite outgrowth and promotes cell death [16]. Based on these findings Tominaga and co-workers suggested that EFhd1 is involved in neuronal differentiation and operates through control of mitochondrial function [16]. Whether this proposed function correlates with the calcium binding activity of EFhd1 is not known at present. Mitochondria, however, are important reservoirs of calcium. Interestingly, ectopic expression of manganese superoxide dismutase 2 (SOD2), a mitochondrial enzyme that inactivates superoxide to protect cells from oxidative damage, induces down-regulation of EFhd1 in a pancreatic carcinoma cell line. Conversely, reduction of SOD2 abundance causes increased EFhd1 expression in a human pancreatic carcinoma cell line (MIA-PaCa2) [95]. At first glance it is therefore puzzling that reduction of SOD2 increases neuronal cell death by activating cell death pathways $[96,97]$. An explanation could be that upregulation of EFhd1 through reduced SOD2 expression [95] may be part of an anti-apoptotic mechanism antagonizing oxidative stress in neuronal cells (Figure 4). An example of a small calcium binding protein antagonizing oxidative stress is calmodulin: After calcium binding, calmodulin interacts with antioxidant enzymes involved in ROS homeostasis [1]. A similar mechanism may apply to EFhd1 in a tissue-specific manner.

Sustained activation of the autocrine IGF-II pathway is critical for myoblast viability and differentiation [98]. Gene expression profiling of IGF-II-deficient myoblasts that undergo apoptosis when incubated in differentiation-promoting medium revealed new mediators of $\mathrm{CBP} / \mathrm{p} 300$ promoted survival. Myoblasts expressing $\mathrm{CBP} / \mathrm{p} 300$ showed a 17 -fold up-regulation of EFhd1 [89]. This indicates that EFhd1 might be a factor causing $\mathrm{CBP} / \mathrm{p} 300$ mediated survival in muscle cells. Interestingly, together with PCAF, the transcriptional co-activator $\mathrm{CBP} / \mathrm{p} 300$ is a key player in neuronal outgrowth by acetylating histones and p53 [99] and exhibits neuroprotective functions [100]. It is tempting to speculate that CBP/p300 up-regulates EFhd1 also in neuronal tissue to promote neuronal survival.

As readily mentioned above, EFhd1 expression has also been described in kidney. This is repressed in renal cell carcinoma (RCC) when compared to healthy tissue [90]. The same holds true for the transcription factor HNF $4 \alpha$ (hepatocyte nuclear factor $4 \alpha$ ). This suggests that HNF $4 \alpha$ exhibits tumour suppressing functions [101]. Interestingly, HNF4 $\alpha$ increases expression of EFhd1, revealing that efhd 1 is a target gene of HNF4 $\alpha$ $[90,102]$. Very recently, an independent microarray analysis confirmed this initial finding [103]. Ectopic HNF $4 \alpha$-expression reduces proliferation in HEK 293 cells (a human embryonic kidney cell line) and therefore, the authors postulate a possible tumour suppressor activity of HNF4 $\alpha$ [102]. However, inducible EFhd1 expression in HEK293 cells revealed that EFhd1 rather augments proliferation slightly [102]. Therefore, efhd 1 is a HNF4 $\alpha$ target gene that appears to oppose the proliferation suppressing effect of HNF4 $\alpha$ in HEK293 cells. Additionally, HNF $4 \alpha$ up-regulates hepatocyte iNOS (inducible nitric oxide synthetase) in response to the inflammatory redox state $[104,105]$. iNOS exhibits antioxidant and anti-apoptotic functions. Hence, it is likely that $\mathrm{HNF} 4 \alpha$ senses the inflammatory redox state in 


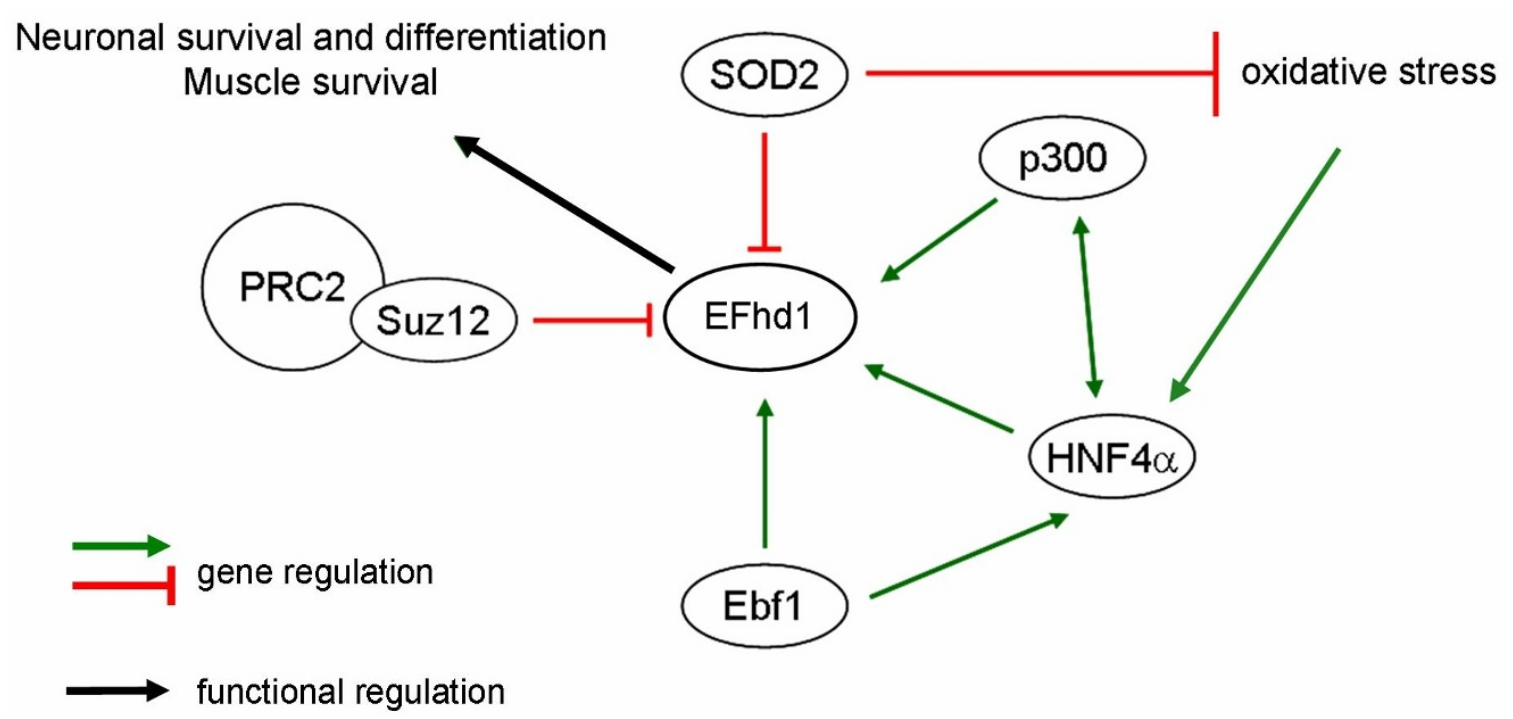

Figure 4 Involvement of EFhd1 in survival and redox regulated pathways. EFhd1 has been described as a survival factor for neuronal cells and been proposed to mediate muscle cell survival. In response to oxidative stress that can be blocked by superoxide dismutase 2 (SOD2), HNF-4 $\alpha$ (hepatocyte nuclear factor $4 \alpha$ ) becomes activated. EFhd1 is a direct target of HNF- $4 \alpha$ and its expression is repressed by SOD2. Thus, EFhd1 may be involved in a protective cellular response against oxidative stress and, thereby, exhibit anti-apoptotic functions in diverse cell types. Early B cell factor 1 (Ebf1) positively regulates EFhd1 expression in early B cells whereas Suz12 as part of the polycomb repressor complex 2 (PRC2) is a negative regulator of EFhd1 expression.

tissues where it is expressed. Taken together, the mitochondrial localization of EFhd1, its ability to promote differentiation of $2 \mathrm{Y}-3 \mathrm{t}$ cells and its converse regulation by the redox factors SOD2 and HNF4 $\alpha$ suggest that EFhd1 is part of a redox-sensitive network controlling cell survival and/or differentiation (Figure 4). Whether EFhd1 is actually a survival promoting or tumour suppressing factor may depend on the cell type and environmental context. For example, under pathological conditions, such as hypoxia and ischemia/reperfusion injury, mitochondrial dysfunction results in ROS increase. Normal tissue responds to this challenge with calcium overload, followed by mitochondrial depolarization, cytochrome c release and apoptosis [1]. Tumours, however, have developed mechanisms to survive hypoxia and ROS increase. One of these factors might be EFhd1.

A combined genome-wide ChIP sequencing analysis with gain- and loss-of-function transcriptome analyses in early-stage B cells identified promoters of genes with Ebf1 (early B cell factor-1) binding sites. IL-7 cultured pro-B cells, in which $E b f 1$ was conditionally inactivated, express less EFhd1 [106], suggesting that efhd1 is a target gene of Ebf1. Hnf4 $\alpha$ was also described as direct target of the transcription factor Ebf1 in common lymphoid progenitors [107] and common lymphoid progenitors are subject to oxidative stress [108]. Thus, Ebf1 may up-regulate EFhd1 through HNF4 $\alpha$. These data point to a function of EFhd1 during early B cell development, an issue we are currently addressing. In contrast to transcriptional activators of efhd1, Suz12 is a transcriptional repressor as part of the transcriptional repressor complex PRC2 (polycomb repressor complex) in murine terato-carcinoma cells [109]. These complexes are normally highly abundant in embryonic tissues and are essential for development. In adult tissues, expression of Suz12 is very low $[110,111]$ but it is very abundant in a variety of human tumours. PRC2 catalyzes trimethylation (me3) of histone 3 lysine 27 (H3K27), thereby, mediating transcriptional repression. Consequently, targeting of the efhd 1 promoter by Suz12 should lead to decreased or no expression of EFhd1.

\section{Conclusions}

Calcium binding proteins of the EF-hand are involved in all aspects of cellular functions. EFhd2 and EFhd1 are two related EF-hand containing adaptor proteins with a similar predicted overall structure. Both proteins bind calcium, but they differ in their sites of expression as well as in their proposed function in different cell types. EFhd2 is a cytoskeleton associated adaptor protein involved in immune and brain cell function and acts likely in response to changes in calcium homeostasis. EFhd1 is involved in neuronal differentiation and operates through control of mitochondrial function. Furthermore EFhd1 could be part of a redox-sensitive network controlling cell survival and/or differentiation depending on the cell type and environmental context. Whereas EFhd1 and EFhd2 are almost identical in the C-terminal part 
containing the EF-hands and the coiled-coil domain, a non-homologous moiety between aa 20-80 in front of the EF-hands shows the most differences between EFhd2 and EFhd1, as well as between orthologues of EFhd2 and EFhd1. As a result, EFhd2 and EFhd1 may bind distinct proteins redundantly while others uniquely, thereby, transmitting alterations in the intracellular calcium concentration into different signaling outcomes. Hence it appears comprehensible that expression of EFhd2 and EFhd1 is tightly controlled and regulated to ensure efficient function of the respective cell type. Besides the compelling necessity to clarify the detailed functions and signaling pathways of EFhd2 and EFhd1 in different cellular contexts, future work has to address possible redundancies of EFhd2 and EFhd1. Therefore, it is reasonable to generate and cross EFhd2 knockout and transgenic mice with the respective Efhd1 mice and analyze the impact in function and development, especially with regard to the immune and nervous system, as well as the progression of tumours.

\section{Additional material}

\section{Additional file 1: Table S1 Murine EFhd1 and EFhd2 genes,}

transcripts and proteins. This table displays the nomenclature of murine EFhd1 and EFhd2 proteins and transcripts as well as gene locus information.

Additional file 2: Figure S1 Aligment of EFhd1 Orthologues Aligment of human (Q9BUP0), murine (Q9D41J), rat (D4A9T5), bovine (Q17QM6) and frog (Q6GP23) EFhd1 using ClustalW2 (http://www.ebi.ac. uk/clustalw). Amino acid (aa) positions are marked on the right. "**", identical aa, ":", conserved aa, "." semi conserved aa.

Additional file 3: Figure S2 Sequence homology of murine AIF-1 with EFhd1 and EFhd2. A standard blast search with murine AIF-1 (AAC82481.1) was performed against all murine non-redundant GenBank CDS translations + PDB + SwissProt + PIR + PRF excluding environmental samples from WGS projects. Homologies between the first EF-hand of AIF-1 and the EF-hands of EFhd1/2 are only shown for the second EF-hands of EFhd1 and EFhd2.

\section{Abbreviations}

aa: amino acid(s); AlF-1: Allograft inflammatory factor-1; BAFF: B cell activating factor of the TNF family; BCR and TCR: B and T cell receptors; $\mathrm{Ca}^{2}$ ${ }^{+}$: Calcium ions; Cdk1: cyclin dependent kinase 1; CRAC: calcium release activated calcium channels; DRM: detergent resistant membranes; Ebf1: early B cell factor-1; EGF: epidermal growth factor; ER: endoplasmic reticulum; FTDP-17: frontotemporal dementia and parkinsonism linked to chromosome 17; GPCR: G-protein coupled receptors; HNF4a: hepatocyte nuclear factor 4a; Ig: immunoglobulin; ITAM: immunoreceptor tyrosine based activation motif; iNOS: inducible nitric oxide synthetase; $\mathrm{P}_{3}$ : inositol-1,4,5-trisphosphate; Iba1: ionized calcium-binding adapter molecule 1; LPS: lipopolysaccharide; NK cells: natural killer cells; PAMP: pathogen associated molecular patterns; PBMC: peripheral blood mononuclear cells; PMA: phorbol myristyl acetate; $\mathrm{PIP}_{2}$ : phosphatidylinositol 4,5 bisphosphate; PRC2: polycomb repressor complex; ROS: reactive oxygen species; RANK-L: receptor activator of NF-KB ligand; RCC: renal cell carcinoma; RA: rheumatoid arthritis; SOCE: store operated calcium entry; STIM: stromal interaction molecule; SOD1/2: superoxide dismutase 1/2; EFhd2: Swiprosin-1/EF-hand containing 2; EFhd1: Swiprosin-2/EF-hand containing 1; UTR: untranslated region

\section{Acknowledgements}

We thank Drs. Roland Lang and Stephan Feller for critical reading of the manuscript. Christina Hornbruch and Dr. Renate Renkawitz-Pohl are acknowledged for critical reading and sharing unpublished data. We thank Sandra Hagen for helpful comments. This work was supported by the DFG (FOR832, Mi832/2-2 and GRK592) and the Interdisciplinary Center for Clinical Research in Erlangen (IZKF Erlangen; grants A7 and E8).

\section{Authors' contributions}

SD and DM collected data, carried out sequence alignments, drafted figures and wrote the manuscript. SB collected data and wrote the manuscript. DM designed and coordinated the study. All authors read and approved the final manuscript.

\section{Competing interests}

The authors declare that they have no competing interests.

Received: 2 December 2010 Accepted: 18 January 2011

Published: 18 January 2011

\section{References}

1. Yan Y, Wei CL, Zhang WR, Cheng HP, Liu J: Cross-talk between calcium and reactive oxygen species signaling. Acta Pharmacol Sin 2006, 27:821-826.

2. Wang D, Feng J, Wen R, Marine JC, Sangster MY, Parganas E, Hoffmeyer A, Jackson CW, Cleveland JL, Murray PJ, Ihle JN: Phospholipase Cgamma2 is essential in the functions of B cell and several Fc receptors. Immunity 2000, 13:25-35.

3. Feske S: Calcium signalling in lymphocyte activation and disease. Nat Rev Immunol 2007, 7:690-702.

4. Varga-Szabo D, Braun A, Nieswandt B: Calcium signaling in platelets. J Thromb Haemost 2009, 7:1057-1066.

5. Berridge MJ, Bootman MD, Lipp P: Calcium-a life and death signal. Nature 1998, 395:645-648

6. Berridge MJ, Lipp P, Bootman MD: The versatility and universality of calcium signalling. Nat Rev Mol Cell Biol 2000, 1:11-21.

7. Carafoli E, Santella L, Branca D, Brini M: Generation, control, and processing of cellular calcium signals. Crit Rev Biochem Mol Biol 2001, 36:107-260.

8. Kretsinger RH, Nockolds CE: Carp muscle calcium-binding protein. II. Structure determination and general description. I Biol Chem 1973, 248:3313-3326.

9. Collins $\mathrm{JH}$ : Homology of myosin light chains, troponin- $\mathrm{C}$ and parvalbumins deduced from comparison of their amino acid sequences. Biochem Biophys Res Commun 1974, 58:301-308.

10. Collins JH, Potter JD, Horn MJ, Wilshire G, Jackman N: The amino acid sequence of rabbit skeletal muscle troponin C: gene replication and homology with calcium-binding proteins from carp and hake muscle. FEBS Lett 1973, 36:268-272.

11. Stevens FC, Walsh M, Ho HC, Teo TS, Wang JH: Comparison of calciumbinding proteins. Bovine heart and brain protein activators of cyclic nucleotide phosphodiesterase and rabbit skeletal muscle troponin C. J Biol Chem 1976, 251:4495-4500.

12. Wang SS, Tsai RY, Reed RR: The characterization of the Olf-1/EBF-like HLH transcription factor family: implications in olfactory gene regulation and neuronal development. J Neurosci 1997, 17:4149-4158.

13. Kawasaki H, Kretsinger RH: Calcium-binding proteins 1: EF-hands. Protein Profile 1995, 2:297-490.

14. Kroczek C, Lang C, Brachs S, Grohmann M, Dutting S, Schweizer A, Nitschke L, Feller SM, Jäck HM, Mielenz D: Swiprosin-1/EFhd2 controls B cell receptor signaling through the assembly of the B cell receptor, Syk, and phospholipase C gamma2 in membrane rafts. J Immunol 2010, 184:3665-3676.

15. Vega IE, Traverso EE, Ferrer-Acosta Y, Matos E, Colon M, Gonzalez J, Dickson D, Hutton M, Lewis J, Yen SH: A novel calcium-binding protein is associated with tau proteins in tauopathy. J Neurochem 2008, 106:96-106, Epub 2008 Jul 2001.

16. Tominaga M, Kurihara H, Honda S, Amakawa G, Sakai T, Tomooka Y: Molecular characterization of mitocalcin, a novel mitochondrial $\mathrm{Ca} 2$ +-binding protein with EF-hand and coiled-coil domains. J Neurochem 2006, 96:292-304. 
17. Wakeland EK, Liu K, Graham RR, Behrens TW: Delineating the genetic basis of systemic lupus erythematosus. Immunity 2001, 15:397-408.

18. van Duijn CM, Dekker MC, Bonifati V, Galjaard RJ, Houwing-Duistermaat JJ, Snijders PJ, Testers L, Breedveld GJ, Horstink M, Sandkuijl LA, van Swieten JC, Oostra BA, Heutink P: Park7, a novel locus for autosomal recessive early-onset parkinsonism, on chromosome 1p36. Am J Hum Genet 2001, 69:629-634.

19. Quinones-Coello AT, Petrella LN, Ayers K, Melillo A, Mazzalupo S, Hudson AM, Wang S, Castiblanco C, Buszczak M, Hoskins RA, Cooley L: Exploring strategies for protein trapping in Drosophila. Genetics 2007, 175:1089-1104.

20. Furlong EE, Andersen EC, Null B, White KP, Scott MP: Patterns of gene expression during Drosophila mesoderm development. Science 2001, 293:1629-1633, Epub 2001 Aug 1622.

21. Estrada B, Choe SE, Gisselbrecht SS, Michaud S, Raj L, Busser BW, Halfon MS, Church GM, Michelson AM: An integrated strategy for analyzing the unique developmental programs of different myoblast subtypes. PLOS Genet 2006, 2:e16, Epub 2006 Feb 17.

22. Kiefer JC: Is your "gene of interest" interesting? Dev Dyn 2007, 236:2962-2969.

23. Shin JH, Yang JW, Le Pecheur M, London J, Hoeger H, Lubec G: Altered expression of hypothetical proteins in hippocampus of transgenic mice overexpressing human Cu/Zn-superoxide dismutase 1. Proteome Sci 2004, 2:2.

24. Martins-de-Souza D, Gattaz WF, Schmitt A, Rewerts C, Maccarrone G, DiasNeto E, Turck CW: Prefrontal cortex shotgun proteome analysis reveals altered calcium homeostasis and immune system imbalance in schizophrenia. Eur Arch Psychiatry Clin Neurosci 2009, 259:151-163.

25. MacLaren EJ, Sikela JM: Cerebellar gene expression profiling and eQTL analysis in inbred mouse strains selected for ethanol sensitivity. Alcohol Clin Exp Res 2005, 29:1568-1579.

26. Zhang AX, Yu WH, Ma BF, Yu XB, Mao FF, Liu W, Zhang JQ, Zhang XM, Li SN, Li MT, Lahn BT, Xiang AP: Proteomic identification of differently expressed proteins responsible for osteoblast differentiation from human mesenchymal stem cells. Mol Cell Biochem 2007, 304:167-179.

27. Nomiyama H, Egami K, Wada N, Tou K, Horiuchi M, Matsusaki H, Miura R, Yoshie O, Kukita T: Identification of genes differentially expressed in osteoclast-like cells. J Interferon Cytokine Res 2005, 25:227-231.

28. Ramesh TP, Kim YD, Kwon MS, Jun CD, Kim SW: Swiprosin-1 Regulates Cytokine Expression of Human Mast Cell Line HMC-1 through Actin Remodeling. Immune Netw 2009, 9:274-284.

29. Thylur RP, Kim YD, Kwon MS, Oh HM, Kwon HK, Kim SH, Im SH, Chun JS, Park ZY, Jun CD: Swiprosin-1 is expressed in mast cells and up-regulated through the protein kinase C beta l/eta pathway. J Cell Biochem 2009, 108:705-715.

30. Mielenz D, Vettermann C, Hampel M, Lang C, Avramidou A, Karas M, Jäck HM: Lipid rafts associate with intracellular $B$ cell receptors and exhibit a B cell stage-specific protein composition. J Immunol 2005, 174:3508-3517.

31. Avramidou A, Kroczek C, Lang C, Schuh W, Jäck HM, Mielenz D: The novel adaptor protein Swiprosin-1 enhances BCR signals and contributes to BCR-induced apoptosis. Cell Death Differ 2007, 14:1936-1947, Epub 2007 Aug 3.

32. Haining WN, Ebert BL, Subrmanian A, Wherry EJ, Eichbaum Q, Evans JW, Mak R, Rivoli S, Pretz J, Angelosanto J, Smutko JS, Walker BD, Kaech SM, Ahmed R, Nadler LM, Golub TR: Identification of an evolutionarily conserved transcriptional signature of $\mathrm{CD} 8$ memory differentiation that is shared by T and B cells. J Immunol 2008, 181:1859-1868.

33. Vuadens F, Rufer N, Kress A, Corthesy P, Schneider P, Tissot JD: Identification of swiprosin 1 in human lymphocytes. Proteomics 2004, 4:2216-2220.

34. Marson A, Kretschmer K, Frampton GM, Jacobsen ES, Polansky JK, Maclsaac KD, Levine SS, Fraenkel E, von Boehmer H, Young RA: Foxp3 occupancy and regulation of key target genes during T-cell stimulation. Nature 2007, 445:931-935

35. Meng X, Wilkins JA: Compositional characterization of the cytoskeleton of NK-like cells. J Proteome Res 2005, 4:2081-2087.

36. Dotzlaw H, Schulz M, Eggert M, Neeck G: A pattern of protein expression in peripheral blood mononuclear cells distinguishes rheumatoid arthritis patients from healthy individuals. Biochim Biophys Acta 2004, 1696:121-129.
37. Schulz M, Dotzlaw H, Mikkat S, Eggert M, Neeck G: Proteomic analysis of peripheral blood mononuclear cells: selective protein processing observed in patients with rheumatoid arthritis. J Proteome Res 2007, 6:3752-3759, Epub 2007 Aug 17.

38. Ballif BA, Carey GR, Sunyaev SR, Gygi SP: Large-scale identification and evolution indexing of tyrosine phosphorylation sites from murine brain J Proteome Res 2008, 7:311-318, Epub 2007 Nov 23.

39. Reynolds AD, Glanzer JG, Kadiu I, Ricardo-Dukelow M, Chaudhuri A, Ciborowski P, Cerny R, Gelman B, Thomas MP, Mosley RL, Gendelman HE: Nitrated alpha-synuclein-activated microglial profiling for Parkinson's disease. J Neurochem 2008, 104:1504-1525.

40. Merkley MA, Hildebrandt E, Podolsky RH, Arnouk H, Ferris DG, Dynan WS, Stoppler H: Large-scale analysis of protein expression changes in human keratinocytes immortalized by human papilloma virus type $16 \mathrm{E} 6$ and E7 oncogenes. Proteome Sci 2009, 7:29.

41. Tamplin OJ, Kinzel D, Cox BJ, Bell CE, Rossant J, Lickert H: Microarray analysis of Foxa2 mutant mouse embryos reveals novel gene expression and inductive roles for the gastrula organizer and its derivatives. BMC Genomics 2008, 9:511.

42. Blagoev B, Ong SE, Kratchmarova I, Mann M: Temporal analysis of phosphotyrosine-dependent signaling networks by quantitative proteomics. Nat Biotechnol 2004, 22:1139-1145.

43. Mocsai A, Ruland J, Tybulewicz VL: The SYK tyrosine kinase: a crucial player in diverse biological functions. Nat Rev Immunol 2010, 10:387-402.

44. Flaswinkel $\mathrm{H}$, Barner $\mathrm{M}$, Reth $\mathrm{M}$ : The tyrosine activation motif as a target of protein tyrosine kinases and SH2 domains. Semin Immunol 1995, 7:21-27.

45. Rolli V, Gallwitz M, Wossning T, Flemming A, Schamel WW, Zurn C, Reth M: Amplification of $B$ cell antigen receptor signaling by a Syk/ITAM positive feedback loop. Mol Cell 2002, 10:1057-1069.

46. Hara $H$, Saito T: CARD9 versus CARMA1 in innate and adaptive immunity. Trends Immunol 2009, 30:234-242.

47. Williams MJ: Drosophila hemopoiesis and cellular immunity. J Immunol 2007, 178:4711-4716

48. Henikoff S, Henikoff JG, Sakai A, Loeb GB, Ahmad K: Genome-wide profiling of salt fractions maps physical properties of chromatin. Genome Res 2009, 19:460-469, Epub 2008 Dec 2016.

49. Xu Y, Liu W, Shen H, Yan J, Yang E, Wang H: Recombinant Mycobacterium bovis BCG expressing chimaeric protein of Ag85B and ESAT-6 enhances immunostimulatory activity of human macrophages. Microbes Infect 2010, 12:683-689.

50. Heasman SJ, Ridley AJ: Mammalian Rho GTPases: new insights into their functions from in vivo studies. Nat Rev Mol Cell Biol 2008, 9:690-701.

51. Park H, Cox D: Cdc42 regulates Fc gamma receptor-mediated phagocytosis through the activation and phosphorylation of WiskottAldrich syndrome protein (WASP) and neural-WASP. Mol Biol Cell 2009, 20:4500-4508.

52. Patel JC, Hall A, Caron E: Vav regulates activation of Rac but not Cdc42 during FcgammaR-mediated phagocytosis. Mol Biol Cell 2002, 13:1215-1226

53. Castellano F, Montcourrier $P$, Chavrier $P$ : Membrane recruitment of Rac1 triggers phagocytosis. J Cell Sci 2000, 113(Pt 17):2955-2961.

54. Leverrier Y, Ridley AJ: Requirement for Rho GTPases and PI 3-kinases during apoptotic cell phagocytosis by macrophages. Curr Biol 2001, 11:195-199.

55. Checinska A, Giaccone G, Rodriguez JA, Kruyt FA, Jimenez CR: Comparative proteomics analysis of caspase-9-protein complexes in untreated and cytochrome c/dATP stimulated lysates of NSCLC cells. J Proteomics 2009, 72:575-585, Epub 2008 Dec 7.

56. Lewis J, McGowan E, Rockwood J, Melrose H, Nacharaju P, Van Slegtenhorst M, Gwinn-Hardy K, Paul Murphy M, Baker M, Yu X, Duff K, Hardy J, Corral A, Lin WL, Yen SH, Dickson DW, Davies P, Hutton M: Neurofibrillary tangles, amyotrophy and progressive motor disturbance in mice expressing mutant (P301L) tau protein. Nat Genet 2000, 25:402-405.

57. Liu G, Ma H, Jiang L, Zhao Y: Allograft inflammatory factor- 1 and its immune regulation. Autoimmunity 2007, 40:95-102.

58. Mishima T, Iwabuchi K, Fujii S, Tanaka SY, Ogura H, Watano-Miyata K, Ishimori N, Andoh Y, Nakai Y, Iwabuchi C, Ato M, Kitabatake A, Tsutsui H, Onoe K: Allograft inflammatory factor-1 augments macrophage phagocytotic activity and accelerates the progression of atherosclerosis in ApoE-/- mice. Int J Mol Med 2008, 21:181-187. 
59. Autieri MV, Chen X: The ability of AIF-1 to activate human vascular smooth muscle cells is lost by mutations in the EF-hand calciumbinding region. Exp Cell Res 2005, 307:204-211.

60. Watano K, Iwabuchi K, Fujii S, Ishimori N, Mitsuhashi S, Ato M, Kitabatake A, Onoe K: Allograft inflammatory factor-1 augments production of interleukin- $6,-10$ and -12 by a mouse macrophage line. Immunology 2001, 104:307-316.

61. Rawlings DJ, Sommer K, Moreno-Garcia ME: The CARMA1 signalosome links the signalling machinery of adaptive and innate immunity in lymphocytes. Nat Rev Immunol 2006, 6:799-812.

62. Sen R: Control of B lymphocyte apoptosis by the transcription factor NFkappaB. Immunity 2006, 25:871-883.

63. Strasser A, Puthalakath $H$, O'Reilly LA, Bouillet $P$ : What do we know about the mechanisms of elimination of autoreactive $T$ and $B$ cells and what challenges remain. Immunol Cell Biol 2008, 86:57-66.

64. Schulze C, Munoz LE, Franz S, Sarter K, Chaurio RA, Gaipl US, Herrmann M: Clearance deficiency-a potential link between infections and autoimmunity. Autoimmun Rev 2008, 8:5-8.

65. Dorner T: Crossroads of B cell activation in autoimmunity: rationale of targeting B cells. J Rheumatol Supp/ 2006, 77:3-11.

66. Ballatore C, Lee VM, Trojanowski JQ: Tau-mediated neurodegeneration in Alzheimer's disease and related disorders. Nat Rev Neurosci 2007, 8:663-672.

67. Lee VM, Goedert M, Trojanowski JQ: Neurodegenerative tauopathies. Annu Rev Neurosci 2001, 24:1121-1159.

68. Giasson Bl, Forman MS, Higuchi M, Golbe LI, Graves CL, Kotzbauer PT, Trojanowski JQ, Lee VM: Initiation and synergistic fibrillization of tau and alpha-synuclein. Science 2003, 300:636-640.

69. Amor S, Puentes F, Baker D, van der Valk P: Inflammation in neurodegenerative diseases. Immunology 2010, 129:154-169.

70. Graeber MB, Lopez-Redondo F, Ikoma E, Ishikawa M, Imai Y, Nakajima K, Kreutzberg GW, Kohsaka S: The microglia/macrophage response in the neonatal rat facial nucleus following axotomy. Brain Res 1998, 813:241-253.

71. Zhai J, Strom AL, Kilty R, Venkatakrishnan P, White J, Everson W, Smart EJ, Zhu H: Proteomic characterization of lipid raft proteins in amyotrophic lateral sclerosis mouse spinal cord. Febs J 2009, 276:3308-3323.

72. Perry JJ, Shin DS, Tainer JA: Amyotrophic lateral sclerosis. Adv Exp Med Biol 2010, 685:9-20.

73. Dimou L, Schnell L, Montani L, Duncan C, Simonen M, Schneider R, Liebscher T, Gullo M, Schwab ME: Nogo-A-deficient mice reveal straindependent differences in axonal regeneration. J Neurosci 2006, 26:5591-5603.

74. Harder T, Engelhardt KR: Membrane domains in lymphocytes - from lipid rafts to protein scaffolds. Traffic 2004, 5:265-275.

75. Harder T, Simons K: Clusters of glycolipid and glycosylphosphatidylinositol-anchored proteins in lymphoid cells: accumulation of actin regulated by local tyrosine phosphorylation. Eur J Immunol 1999, 29:556-562.

76. Benarroch EE: Lipid rafts, protein scaffolds, and neurologic disease. Neurology 2007, 69:1635-1639.

77. Wechsler RJ, Monroe JG: Immature B lymphocytes are deficient in expression of the src-family kinases p59fyn and p55fgr1. J Immunol 1995, 154:1919-1929.

78. Numazaki M, Kato C, Kawauchi Y, Kajiwara T, Ishii M, Kojima N: Crosslinking of SIGNR1 activates JNK and induces TNF-alpha production in RAW264.7 cells that express SIGNR1. Biochem Biophys Res Commun 2009, 386:202-206

79. Link DC, Zutter M: The proto-oncogene c-fgr is expressed in normal mantle zone $B$ lymphocytes and is developmentally regulated during myelomonocytic differentiation in vivo. Blood 1995, 85:472-479.

80. Blethrow JD, Glavy JS, Morgan DO, Shokat KM: Covalent capture of kinasespecific phosphopeptides reveals Cdk1-cyclin B substrates. Proc Natl Acad Sci USA 2008, 105:1442-1447, Epub 2008 Jan 1430.

81. Dephoure N, Zhou C, Villen J, Beausoleil SA, Bakalarski CE, Elledge SJ, Gygi SP: A quantitative atlas of mitotic phosphorylation. Proc Natl Acad Sci USA 2008, 105:10762-10767, Epub 12008 Jul 31

82. Zanivan S, Gnad F, Wickstrom SA, Geiger T, Macek B, Cox J, Fassler R, Mann M: Solid Tumor Proteome and Phosphoproteome Analysis by High Resolution Mass Spectrometry. J Proteome Res 2008, 31:31.

83. Weintz G, Olsen JV, Fruhauf K, Niedzielska M, Amit I, Jantsch J, Mages J, Frech C, Dolken L, Mann M, Lang R: The phosphoproteome of toll-like receptor-activated macrophages. Mol Syst Biol 2010, 6:371.
84. Castedo M, Perfettini $J$, Roumier T, Kroemer G: Cyclin-dependent kinase-1: linking apoptosis to cell cycle and mitotic catastrophe. Cell Death Differ 2002, 9:1287-1293.

85. Banerjee SK, Weston AP, Zoubine MN, Campbell DR, Cherian R: Expression of cdc2 and cyclin B1 in Helicobacter pylori-associated gastric MALT and MALT lymphoma: relationship to cell death, proliferation, and transformation. Am J Pathol 2000, 156:217-225.

86. Yamashita Y, Miyake K, Miura Y, Kaneko Y, Yagita H, Suda T, Nagata S, Nomura J, Sakaguchi N, Kimoto M: Activation mediated by RP105 but not CD40 makes normal B cells susceptible to anti-lgM-induced apoptosis: a role for Fc receptor coligation. J Exp Med 1996, 184:113-120.

87. Gupta N, Wollscheid B, Watts JD, Scheer B, Aebersold R, DeFranco AL: Quantitative proteomic analysis of B cell lipid rafts reveals that ezrin regulates antigen receptor-mediated lipid raft dynamics. Nat Immunol 2006, 7:625-633, Epub 2006 Apr 30.

88. Tominaga $M$, Tomooka $Y$ : Novel genes cloned from a neuronal cell line newly established from a cerebellum of an adult p53(-/-) mouse. Biochem Biophys Res Commun 2002, 297:473-479.

89. Kuninger $D$, Wright $A$, Rotwein $P$ : Muscle cell survival mediated by the transcriptional coactivators p300 and PCAF displays different requirements for acetyltransferase activity. Am J Physiol Cell Physiol 2006 291:C699-709.

90. Lucas B, Grigo K, Erdmann S, Lausen J, Klein-Hitpass L, Ryffel GU: HNF4alpha reduces proliferation of kidney cells and affects genes deregulated in renal cell carcinoma. Oncogene 2005, 24:6418-6431.

91. Mandruzzato S, Callegaro A, Turcatel G, Francescato S, Montesco MC, Chiarion-Sileni V, Mocellin S, Rossi CR, Bicciato S, Wang E, Marincola FM, Zanovello P: A gene expression signature associated with survival in metastatic melanoma. J Trans/ Med 2006, 4:50.

92. Vanharanta S, Wortham NC, Laiho P, Sjoberg J, Aittomaki K, Arola J, Tomlinson IP, Karhu A, Arango D, Aaltonen LA: 7q deletion mapping and expression profiling in uterine fibroids. Oncogene 2005, 24:6545-6554.

93. Winn VD, Haimov-Kochman R, Paquet AC, Yang YJ, Madhusudhan MS, Gormley M, Feng KT, Bernlohr DA, McDonagh S, Pereira L, Sali A, Fisher SJ: Gene expression profiling of the human maternal-fetal interface reveals dramatic changes between midgestation and term. Endocrinology 2007, 148:1059-1079.

94. Popovici RM, Betzler NK, Krause MS, Luo M, Jauckus J, Germeyer A, Bloethner S, Schlotterer A, Kumar R, Strowitzki T, von Wolff M: Gene expression profiling of human endometrial-trophoblast interaction in a coculture model. Endocrinology 2006, 147:5662-5675.

95. Hurt EM, Thomas SB, Peng B, Farrar WL: Molecular consequences of SOD2 expression in epigenetically silenced pancreatic carcinoma cell lines. Br J Cancer 2007, 97:1116-1123.

96. Kim GW, Chan PH: Involvement of superoxide in excitotoxicity and DNA fragmentation in striatal vulnerability in mice after treatment with the mitochondrial toxin, 3-nitropropionic acid. J Cereb Blood Flow Metab 2002, 22:798-809.

97. Noshita N, Sugawara T, Fujimura M, Morita-Fujimura Y, Chan PH: Manganese Superoxide Dismutase Affects Cytochrome c Release and Caspase-9 Activation After Transient Focal Cerebral Ischemia in Mice. J Cereb Blood Flow Metab 2001, 21:557-567.

98. Stewart CE, Rotwein P: Insulin-like growth factor-II is an autocrine survival factor for differentiating myoblasts. J Biol Chem 1996, 271:11330-11338.

99. Gaub P, Tedeschi A, Puttagunta R, Nguyen T, Schmandke A, Di Giovanni S: HDAC inhibition promotes neuronal outgrowth and counteracts growth cone collapse through CBP/p300 and P/CAF-dependent p53 acetylation. Cell Death Differ 2010, 17:1392-1408.

100. Rouaux C, Jokic N, Mbebi C, Boutillier S, Loeffler JP, Boutillier AL: Critical loss of CBP/p300 histone acetylase activity by caspase- 6 during neurodegeneration. Embo J 2003, 22:6537-6549.

101. Lenburg ME, Liou LS, Gerry NP, Frampton GM, Cohen HT, Christman MF: Previously unidentified changes in renal cell carcinoma gene expression identified by parametric analysis of microarray data. BMC Cancer 2003, 3:31.

102. Grigo K, Wirsing A, Lucas B, Klein-Hitpass L, Ryffel GU: HNF4 alpha orchestrates a set of 14 genes to down-regulate cell proliferation in kidney cells. Biol Chem 2008, 389:179-187.

103. Bolotin E, Liao H, Ta TC, Yang C, Hwang-Verslues W, Evans JR, Jiang T, Sladek FM: Integrated approach for the identification of human 
hepatocyte nuclear factor 4alpha target genes using protein binding microarrays. Hepatology 2010, 51:642-653.

104. Guo H, Cai CQ, Kuo PC: Hepatocyte nuclear factor-4alpha mediates redox sensitivity of inducible nitric-oxide synthase gene transcription. J Biol Chem 2002, 277:5054-5060.

105. Guo H, Wei J, Inoue Y, Gonzalez FJ, Kuo PC: Serine/threonine phosphorylation regulates HNF-4alpha-dependent redox-mediated iNOS expression in hepatocytes. Am J Physiol Cell Physiol 2003, 284:C1090-1099.

106. Treiber T, Mandel EM, Pott S, Gyory I, Firner S, Liu ET, Grosschedl R: Early B cell factor 1 regulates $B$ cell gene networks by activation, repression, and transcription- independent poising of chromatin. Immunity 2010, 32:714-725.

107. Zandi S, Mansson R, Tsapogas P, Zetterblad J, Bryder D, Sigvardsson M: EBF1 is essential for B-lineage priming and establishment of a transcription factor network in common lymphoid progenitors. J Immunol 2008, 181:3364-3372.

108. Tothova Z, Kollipara R, Huntly BJ, Lee BH, Castrillon DH, Cullen DE, McDowell EP, Lazo-Kallanian S, Williams IR, Sears C, Armstrong SA Passegue E, DePinho RA, Gilliland DG: FoxOs are critical mediators of hematopoietic stem cell resistance to physiologic oxidative stress. Cell 2007, 128:325-339

109. Squazzo SL, O'Geen H, Komashko VM, Krig SR, Jin VX, Jang SW, Margueron R, Reinberg D, Green R, Farnham PJ: Suz12 binds to silenced regions of the genome in a cell-type-specific manner. Genome Res 2006, 16:890-900.

110. Kirmizis A, Bartley SM, Kuzmichev A, Margueron R, Reinberg D, Green R, Farnham PJ: Silencing of human polycomb target genes is associated with methylation of histone H3 Lys 27. Genes Dev 2004, 18:1592-1605.

111. Kuzmichev A, Margueron R, Vaquero A, Preissner TS, Scher M, Kirmizis A, Ouyang X, Brockdorff N, Abate-Shen C, Farnham P, Reinberg D: Composition and histone substrates of polycomb repressive group complexes change during cellular differentiation. Proc Natl Acad Sci USA 2005, 102:1859-1864

doi:10.1186/1478-811X-9-2

Cite this article as: Dütting et al:: Fraternal twins: Swiprosin-1/EFhd2 and Swiprosin-2/EFhd1, two homologous EF-hand containing calcium

binding adaptor proteins with distinct functions. Cell Communication and Signaling 2011 9:2.

\section{Submit your next manuscript to BioMed Central and take full advantage of:}

- Convenient online submission

- Thorough peer review

- No space constraints or color figure charges

- Immediate publication on acceptance

- Inclusion in PubMed, CAS, Scopus and Google Scholar

- Research which is freely available for redistribution

Submit your manuscript at www.biomedcentral.com/submit 